JIPVA (JURNAL PENDIDIKAN IPA VETERAN)

Volume 3 - Nomor 1, 2019

Available at http://e-journal.ivet.ac.id/index.php/jipva

ISSN : 2598-5876 (print), 2598-0904 (online)

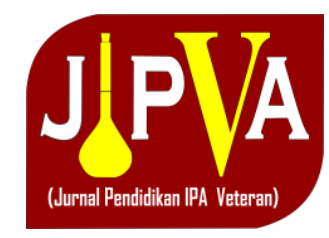

\title{
Efek kooperatif-talking chips terintegrasi video pembelajaran pada hasil belajar siswa
}

Qurratun Khairina $^{1 *}$, Nofri Yuhelman ${ }^{2}$, Jumriana Rahayuningsih ${ }^{3}$

Pendidikan Kimia, Fakultas Tarbiyah dan Keguruan, Universitas Islam Kuantan Singingi

Kuantan Singingi, Riau, Indonesia

*Coressponding author email: qurratunk@gmail.com

\begin{tabular}{l}
\hline Artikel info \\
\hline Received $: 26$ November 2018 \\
Revised $: 11$ April 2019 \\
Accepted $: 18$ April 2018
\end{tabular}

Kata kunci:

Hasil belajar

Pembelajaran kooperatif

Talking chips

Video pembelajaran

\begin{abstract}
ABSTRAK
Model kooperatif tipe talking chips memberikan kesempatan kepada siswa untuk aktif dalam proses pembelajaran. Penelitian ini bertujuan untuk menginvestigasi pengaruh pembelajaran kooperatif tipe talking chips berbantuan video pembelajaran untuk meningkatkan hasil belajar siswa pada pokok bahasan tata nama senyawa. Penelitian tindakan kelas ini dilaksanakan di kelas X TSM 2 SMKN 1 Teluk Kuantan. Teknik pengumpulan data menggunakan observasi, tes dan dokumentasi. Analisis data menggunakan perhitungan persentase ketuntasan hasil belajar siswa. Hasil analisis menunjukkan bahwa ketuntasan klasikal pada siklus I sebesar $60 \%$ dan siklus II sebesar $85 \%$. Oleh karena itu, terdapat peningkatan hasil belajar siswa dari siklus I ke siklus II sebesar $25 \%$. Berdasarkan hasil penelitian disimpulkan bahwa model pembelajaran kooperatif tipe Talking Chips berbantuan video pembelajaran dapat meningkatkan hasil belajar siswa pada materi tata nama senyawa.
\end{abstract}

\section{ABSTRACT}

Keywords:

Cooperative learning

Learning outcomes

Learning videos

Talking chips

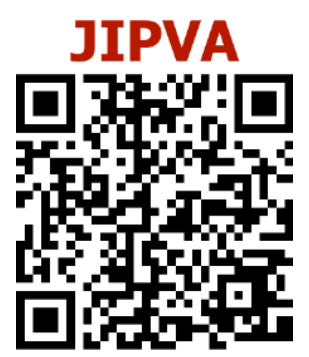

Cooperative learning model talking chips type assisted by video learning to improve learning outcomes on the subject matter of compound names. The cooperative model of talking chips type provides an opportunity for students to be active in the learning process. This study aims to investigate the effect of cooperative learning talking chips type assisted with video learning to improve student learning outcomes on the subject matter of compound names. This classroom action research was conducted in class X TSM 2 of SMK 1 Teluk Kuantan. The technique of collecting data uses observation, tests and documentation. Data analysis using the calculation of the percentage of completeness of student learning outcomes. The results of the analysis showed that classical completeness in the first cycle was $60 \%$ and the second cycle was $85 \%$. Therefore, there is an increase in student learning outcomes from cycle I to cycle II by $25 \%$. Based on the results of the study it was concluded that the cooperative learning model of the Talking Chips type assisted with learning videos could improve student learning outcomes in the compound nomenclature material.

How to Cite : Khairina, Q., Yuhelman, N., Rahayuningsih' J. (2019). Efek kooperatif-talking chips terintegrasi video pembelajaran pada hasil belajar siswa. JIPVA (Jurnal Pendidikan IPA Veteran), 3(1), 77 86, doi: https://doi.org/10.31331/jipva.v3i1.739

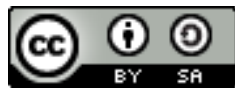

Copyright (C) 2019, Khairina et al. 


\section{PENDAHULUAN}

Dalam mewujudkan tujuan pendidikan, kegiatan belajar mengajar merupakan hal yang paling urgen. Setiap komponen dalam proses pembelajaran memegang peranan sangat penting, mulai dari perencanaan (Kusumaningrum \& Djukri, 2016), pelaksanaan kegiatan sampai evaluasi (Hamdu \& Agustina, 2011) dan program tindak lanjut (Suryosubroto, 2009). Selama proses pembelajaran, siswa dituntut untuk aktif (Susilowati, Iswari, \& Sukaesih, 2013), mandiri, dan bertanggung jawab untuk mencapai hasil belajar yang maksimal (Dewi, Sugiarta, \& Suarsana, 2015). Hasil belajar akan terukur sebagai penentu ketercapaian tujuan pembelajaran sebagai tolok ukur keberhasilan suatu proses pembelajaran.

Pada pembelajaran, siswa dilibatkan sepenuhnya dan diarahkan untuk mampu menemukan dan mengkonstruksi sendiri pengetahuannya (Firdaus \& Wilujeng, 2018; Sari \& Sugiyarto, 2015; Tivani \& Paidi, 2016) serta dilatih untuk menggali dan mengolah informasi, mengambil keputusan secara tepat, dan memecahkan masalah sehingga proses pembelajaran yang lebih bermakna (Putrayasa, Syahruddin, \& Margunayasa, 2014). Akan tetapi, pembelajaran yang mengarahkan siswa untuk mampu membangun pemahaman materi secara mandiri masih sangat kurang (Insyasiska, Zubaidah, \& Susilo, 2015). Berdasarkan observasi yang telah dilakukan pada pembelajaran kimia di SMKN 1 Teluk Kuantan di kelas X TSM 2, model pembelajaran yang digunakan guru masih konvensional serta belum memaksimalkan penggunaan media pembelajaran. Siswa cenderung kurang aktif dalam pembelajaran. Hasil wawancara dengan guru kimia kelas $\mathrm{X}$ menunjukkan bahwa beberapa siswa masih kesulitan untuk menyelesaikan soal-soal terkait materi tata nama senyawa, dan nilai rata-rata siswa pada materi tersebut belum mencapai kriteria ketuntasan minimum (KKM).

Hasil belajar siswa yang kurang maksimal (Handayani, Prihatin, \& Fikri, 2018) dan minat belajar siswa yang rendah merupakan problematika yang sering dihadapi oleh guru (Hamdu \& Agustina, 2011). Andriani (2017) menambahkan bahwa penggunaan model pembelajaran yang kurang bervariasi dapat menurunkan motivasi siswa dan berimbas pada kurang berkembangnya rasa keingintahuan siswa terhadap obyek yang menjadi materi pokok. Permasalahan tersebut dapat diatasi dengan melibatkan siswa secara aktif pada setiap tahapan pembelajaran.

Kemajuan Teknologi Informasi dan Komunikasi memberikan berbagai kemudahan dalam pembelajaran (Gutmann, Kühbeck, Berberat, \& Fischer, 2015; Kusmana, 2011). Hal ini memungkinkan terjadinya pergeseran orientasi proses pembelajaran dari outside-guided menjadi selfguided, dari knowledge-as-possesion menjadi knowledge-as-construction (Nugroho, 2010). Untuk menunjang pembelajaran di kelas diperlukan sarana dan prasarana pendukung, misalnya media pembelajaran (Widiyawati \& Nurwahidah, 2018). Melalui penggunaan media pembelajaran, komunikasi guru dan siswa dapat berjalan lancar sehingga materi dapat tersampaikan secara maksimal (Asmarnis, Yuhelman, \& Murwindra, 2016; Taufiq, Dewi, \& Widiyatmoko, 2014). Salah satu media yang dapat digunakan yaitu video pembelajaran. Media tersebut dapat mengakomodasi karakteristik belajar siswa tipe audio maupun visual dengan baik (Kurniawan, 2014). Penggunaan video pembelajaran dapat menunjang tercapainya tujuan pembelajaran.

Berdasarkan permasalahan tersebut, maka harus ada tindakan yang dilakukan agar hasil belajar siswa meningkat. Guru dapat menggunakan variasi model pembelajaran dan media 
pembelajaran. Salah satunya model pembelajaran kooperatif atau Cooperative Learning tipe Talking Chips berbantuan video pembelajaran. Model kooperatif memberikan suasana pembelajaran yang menyenangkan sehingga akan memotivasi siswa untuk dapat terlibat secara aktif (Hariyanto \& Asto, 2015) dalam menemukan dan memahami konsep materi secara mandiri (Dewi et al., 2015), meningkatkan kerjasama serta menumbuhkan solidaritas antar teman (Lestari, 2012). Salah satu tipe pembelajaran kooperatif yaitu Talking Chips. Penggunaan model pembelajaran kooperatif tipe Talking Chips mampu membuat siswa berperan aktif dalam belajar kelompok. Setiap anggota di dalam kelompok akan mendapatkan kesempatan yang sama untuk memberikan pendapat dan mendengarkan pandangan serta pemikiran anggota kelompok yang lain (Hasairin \& Apriyanti, 2018). Pada tipe Talking Chips siswa dibagi menjadi beberapa kelompok kecil, setiap siswa diberi kancing. Setiap kancing akan diletakkan pada kotak yang tersedia pada masing-masing kelompok jika siswa bertanya, menjawab pertanyaan, atau mengemukakan pendapat. Jika kancing telah habis maka siswa tidak boleh berbicara lagi sampai kancing yang dimiliki temannya juga habis (Yanda, Asrul, \& Yusnetti, 2013). Melalui pembelajaran tersebut diharapkan hasil belajar siswa akan meningkat.

Penelitian terdahulu menyatakan bahwa penggunaan video pembelajaran dapat mengoptimalkan kemampuan kognitif siswa (Alimah, 2012; Busyaeri, Udin, \& Zaenudin, 2016), meningkatkan motivasi belajar (Yusuf, Amin, \& Nugrahaningsih, 2017) dan kemampuan berpikir kritis siswa (Sari \& Sugiyarto, 2015). Sedangkan hasil penelitian terdahulu mengenai model Talking Chips menunjukkan bahwa penerapan model pembelajaran tersebut meningkatkan aktivitas belajar siswa di kelas. Siswa yang memiliki aktivitas belajar yang tinggi akan berperan aktif dalam pembelajaran, hal ini berimbas pada hasil belajar yang maksimal (Bayharti, Bahrizal, \& Fitriani, 2017; Rhochani \& A'yun, 2018; Satriani et al., 2018 ; Wibawa, Wirya, \& Tegeh, 2016). Namun, belum ada penelitian yang memadukan pemanfaatan video pembelajaran dengan model Talking Chips. Oleh karena itu, penting untuk dilakukan penelitian yang mengkombinasikan penggunaan model Talking Chips berbantuan video pembelajaran.

Berdasarkan permasalah yang telah diuraikan, maka perlu dilakukan penelitian mengenai penerapan model pembelajaran kooperatif tipe talking chips berbantuan video pembelajaran untuk meningkatkan hasil belajar siswa pada materi tata nama senyawa.

\section{METODE}

\section{Jenis Penelitian}

Penelitian ini termasuk ke dalam jenis penelitian tindakan kelas (PTK).

\section{Waktu dan Tempat Penelitian}

Penelitian ini dilaksanakan pada bulan Januari sampai dengan bulan Mei 2018 di SMK Negeri 1 Teluk Kuantan yang beralamat di Jalan Belibis Kecamatan Kuantan Tengah Kabupaten Kuantan Singingi. Penelitian dilakukan selama 2 kali tatap muka yaitu dalam 2 siklus.

\section{Subjek Penelitian}


Subjek dari penelitian tindakan kelas ini yaitu siswa kelas X TSM 2 di SMKN 1 Teluk Kuantan yang berjumlah 20 orang.

\section{Prosedur}

Penelitian ini dilakukan dalam dua siklus pembelajaran. Penelitian tindakan kelas di tandai dengan adanya tindakan. Tindakan tersebut dilakukan tidak hanya sekali tetapiberulang-ulang agar tujuan penelitian yang diharapkan dapat tercapai. Setiap tindakan terdiri atas rangkaian empat kegiatan, yaitu perencanaan, tindakan, pengamatan dan refleksi.

Pada tahap perencanaan, hal yang dilakukan yakni a) menetapkan materi yang akan diajarkan yaitu tata nama senyawa; b) menyusun rancangan pelaksanaan pembelajaran (RPP) dengan model pembelajaran Talking Chips untuk masing-masing siklus; c) menyiapkan lembar kerja siswa (LKS); d) membuat lembar observasi aktifitas guru dan siswa; e) membuat alat evaluasi berupa soal-soal yang akan di berikan setelah pelaksanaan proses belajar mengajar pada masing-masing siklus. Perangkat yang telah disusun selanjutnya dikonsultasikan kepada rekan sejawat, dan dilakukan revisi berdasarkan kritik dan saran yang diberikan. Soal-soal evaluasi yang akan digunakan diujicobakan kepada siswa yang telah mendapatkan materi tata nama senyawa untuk memperoleh data kevalidannya.

Langkah-langkah yang dilakukan pada tahap tindakan yaitu a) melaksanakan proses belajar mengajar sesuai dengan RPP yang telah disiapkan; dan b) melaksanakan tes akhir tindakan pada masing-masing siklus untuk mengetahui ada tidaknya peningkatan hasil belajar melalui penerapan model pembelajaran Talking Chips berbantuan video pembelajaran.

Tahap selanjutnya yaitu pengamatan, pengumpulan data dilakukan melalui observasi. Pengamatan dilakukan oleh dua orang observer yakni guru bidang studi kimia yang ada di sekolah. Hal yang diamati berupa kegiatan guru dan data kegiatan siswa selama proses belajar mengajar dilaksanakan. Tahap terakhir yaitu melakukan refleksi terhadap kegiatan pembelajaran yang dilakukan sehingga dapat disimpulkan kekuatan dan kelemahan dari tindakan yang telah dilakukan, penyebab dan penyelesaian permasalahan yang muncul dalam proses pembelajaran.

Jika kemampuan guru dalam mengelola pembelajaran dan aktivitas siswa belum maksimal dan masih banyak terdapat kelemahan, maka pembelajaran dilanjutkan ke siklus selanjutnya. Pada pertemuan selanjutnya, guru perlu memperbaiki kelemahan yang terdapat pada siklus I tersebut agar proses pembelajaran lebih baik. Jika hasil ketuntasan belajar siswa kurang dari $85 \%$ maka pembelajaran tersebut harus dilanjutkan kepada siklus selanjutnya dan jika ketuntasan belajar siswa $\geq 85 \%$ maka pembelajaran tersebut dapat tercapai dan siklus dapat dihentikan.

\section{Teknik Pengumpulan Data}

Pengumpulan data dilakukan melalui teknik observasi, pemberian tes dan dokumentasi. Obervasi dilakukan oleh observer dengan mengisi lembar observasi aktivitas guru dan siswa dengan cara memberikan tanda centang pada kolom yang disediakan yang sesuai dengan deskriptor yang teramati.Tes yang diberikan kepada siswa berupa soal-soal pertanyaan kepada siswa untuk mengetahui bagaimana hasil belajar siswa tersebut. Tes diberikan kepada siswa kelas X TSM 2 di SMKN 1 Teluk Kuantan. Tes tersebut berupa soal uraian yang terdiri dari 15 soal pilihan ganda pada setiap siklusnya. Tes tersebut di analisis butir soal terlebih dahulu 
untuk mengetahui apakah tes tersebut layak digunakan atau tidak. Untuk mengetahui kelayakan tes tersebut digunakan teknik validitas isi. Validitas isi dilakukan judgment oleh tiga orang validator yang diberikan butir - butir soal untuk pengumpulan data. Selanjutnya melakukan dokumentasi nilai postest pada materi tata nama senyawa siswa kelas X TSM 2 di SMKN 1 Teluk Kuantan.

\section{Teknik Analisis Data}

Data yang diperoleh dalam penelitian tindakan kelas, ada dua jenis data yakni data kuantitatif dan data kualitatif. Data kuantitatif yang diperoleh dari hasil observasi aktivitas guru dan siswa kemudian dianalisis menggunakan teknik analisis yang disajikan dalam persamaan (1) (Sukardi, 2012).

$$
\mathrm{P}=\frac{f}{N} \times 100 \%
$$

Keterangan

$\mathrm{P} \quad=$ persentase penilaian

$\mathrm{f} \quad=$ frekuensi

$\mathrm{N} \quad=$ Jumlah aktivitas keseluruhan

Data dari persentase yang didapatkan dari persamaan (1) selanjutnya diubah menjadi data kualitatif dengan menggunakan kriteria penilaian yang dapat dilihat pada Tabel 1 .

Tabel 1. Kriteria aktivitas guru dan siswa (Sukardi, 2012)

\begin{tabular}{cc}
\hline Skor & Kategori \\
\hline $86 \%-100 \%$ & Sangat Baik \\
\hline $76 \%-85 \%$ & Baik \\
\hline $60 \%-75 \%$ & Cukup \\
\hline $55 \%-59 \%$ & Kurang \\
\hline$>54 \%$ & Sangat Kurang \\
\hline
\end{tabular}

Data kuantitatif berupa hasil belajar pada setiap siklusnya. Apabila hasil belajar siswa belum mencapai tujuan dengan kriteria $85 \%$ dari target yang diharapkan, dengan demikian pengajaran tersebut gagal dan harus diulang kembali. Adapun analisis datanya menggunakan persamaan 2 .

$$
\mathrm{KI}=\frac{T}{T_{t}} \times 100 \%
$$

Keterangan:

$\mathrm{KI}=$ Ketuntasan Individu

$\mathrm{T}=$ Jumlah skor yang diperoleh siswa

$\mathrm{Tt}=$ Jumlah skor total

Sedangkan rumus yang digunakan untuk melihat ketuntasan belajar siswa secara klasikal menggunakan persamaan 3.

$$
\mathrm{KS}=\frac{S T}{N} \times 100 \%
$$

Keterangan:

$\mathrm{KS}=$ Ketuntasan Klasikal 


$$
\begin{aligned}
& \mathrm{ST}=\text { Jumlah siswa yang tuntas } \\
& \mathrm{N}=\text { Jumlah siswa dalam kelas }
\end{aligned}
$$

Ketuntasan individu akan tercapai apabila setiap siswa nilainya mencapai KKM (Kriteria Ketuntasan Minimun) yang ditetapkan pada materi tata nama senyawa yakni 70 dan ketuntasan klasikal akan tercapai apabila suatu kelas dikatakan tuntas belajarnya jika dalam kelas tersebut terdapat $\geq 85 \%$ siswa yang telah tuntas belajarnya. Adapun nilai KKM (kriteria ketuntasan minimum).

\section{HASIL DAN PEMBAHASAN}

\section{Hasil Penelitian}

Uji coba instrumen soal dilakukan oleh tiga orang validator dimana ada soal yang di uji cobakan ada 46 soal yang terdiri dari soal siklus I dan soal siklus II. Tes tersebut dikatakan valid apabila persentase dari ketiga validator lebih dari 53\%. Berdasarkan analisis instrumen diperoleh bahwa ada 3 soal yang tidak layak untuk digunakan dan ada 43 soal yang layak untuk digunakan. Namun, hanya dipilih 30 soal saja yang akan digunakan sebagai soal evaluasi pada penelitian ini. Hal ini didasarkan pada daya beda soal dan tingkat kesulitannya. Pada penelitian yang akan dilaksanakan pada siklus I menggunakan 15 soal dan pada siklus II menggunakan 15 soal.

Berdasarkan hasil penelitian yang diperoleh dari lembar observasi aktivitas guru dan lembar observasi aktivitas siswa, dapat dilihat presentase aktivitas guru dan aktivitas siswa yang disajikan pada Tabel 2.

Tabel 2. Persentase aktivitas guru dan aktivitas siswa

\begin{tabular}{ccc} 
Siklus & Aktivitas Guru & Aktivitas Siswa \\
\hline I & $80 \%$ & $78,57 \%$ \\
\hline II & $100 \%$ & $100 \%$
\end{tabular}

Untuk hasil belajar siswa dilihat dari nilai posttest yang diberikan pada saat pembelajaran siklus I telah dilaksanakan adapun kriteria ketuntasan minimum yang digunakan adalah. 70 dengan standar ketuntasan klasikalnya 85\%. Berikut disajikan tabel ketuntasan belajar siswa pada Tabel 3. Perbandingan ketuntasan belajar pada siklus I dan II disajikan pada Gambar 1.

Tabel 3. Persentase hasil belajar

\begin{tabular}{cccc}
\hline Pencapaian Aspek & Siklus I (\%) & Siklus II (\%) & Peningkatan $(\%)$ \\
\hline Hasil Belajar & 60 & 85 & 25 \\
\hline
\end{tabular}




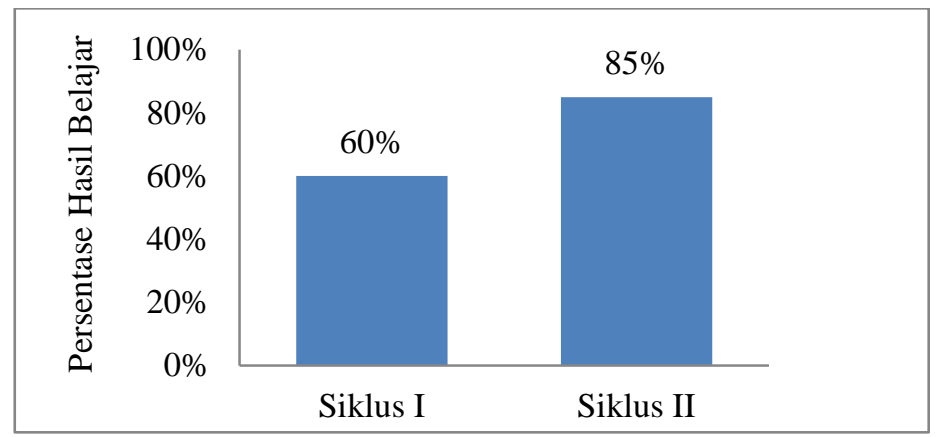

Gambar 1. Ketuntasan belajar siswa

\section{Pembahasan}

Berdasarkan lembar observasi guru, diperoleh aktivitas guru pada siklus I sebesar $80 \%$. Hal ini berarti bahwa guru masih mempunyai kelemahan terhadap pembelajaran yang di laksanakan dan memperbaiki kelemahan yang terjadi pada siklus I pada siklus selanjutnya. Berdasarkan lembar observasi aktivitas siswa, diperoleh aktivitas siswa pada siklus I sebesar 78,57\%. Hal ini berarti aktivitas siswa belum terlaksana sepenuhnya dan masih terdapat kelemahan dalam pembelajaran. Pada siklus I persentase ketuntasan klasikal siswa sebesar $60 \%$ dan belum mencapai nilai ketuntasan klasikal yakni $85 \%$.

Berdasarkan hal tersebut di peroleh bahwa ada beberapa kelemahan yang terdapat pada siklus I yakni pertama ada siswa yang kurang aktif dalam kelompoknya. Kedua ada siswa yang membawa buku ketika mempresentasikan hasil diskusi kelompoknya dan ketiga hasil belajar siswa rendah. Sehingga di harapkan pada pertemuan selanjutnya guru lebih memfokuskan kepada siswa yang kurang aktif dan meminta siswa tidak membawa buku ketika mempresentasikan hasil diskusinya ke depan kelas serta mengingatkan siswa untuk belajar dengan sungguh - sungguh baik di sekolah maupun di rumah. Untuk itu pembelajaran akan dilanjutkan ke siklus selanjutnya.

Pada siklus II lembar observasi guru diperoleh persentase sebesar 100\%. Hal ini berarti pada siklus II guru sudah memperbaiki kelemahan yang terjadi pada siklus I. Pada siklus II lembar aktivitas siswa diperoleh persentase 100\%. Hal ini berarti aktivitas siswa sudah terlaksana semuanya. Pada siklus II persentase ketuntasan klasikan siswa sebesar 85\%. Hal ini berarti terjadi peningkatan hasil belajar dari siklus I ke siklus II yakni sebesar $25 \%$.

Sesuai dengan kriteria ketuntasan belajar secara klasikal di sekolah dinyatakan tuntas apabila $85 \%$ siswa tuntas secara klasikal. Sehingga dapat dikatakan ketuntasan belajar secara klasikal pada siklus II tercapai dan pembelajaran tidak perlu dilanjutkan pada siklus selajutnya. Hal ini menunjukkan bahwa penerapan model pembelajaran kooperatif tipe Talking Chips berbantuan media audio visual dapat meningkatkan hasil belajar pada materi tata nama senyawa kelas X TSM 2 di SMK Negeri 1 Teluk Kuantan. Hal ini sejalan dengan hasil penelitian Alimah (2012) yang menunjukkan bahwa penggunaan video pembelajaran dapat memaksimalkan pemaham kognitif siswa sehingga hasil belajarnya meningkat. Sejalan dengan itu, penelitian yang dilakukan Busyaeri, Udin, \& Zaenudin (2016) serta Yusuf et al. (2017) menunjukkan bahwa penggunaan video pembelajaran akan meningkatkan motivasi belajar sehingga berpengaruh baik terhadap motivasi belajarannya. Penelitian lain yang dilakukan oleh Satriani et al. (2018) menambahkan bahwa penggunaan model Talking Chips dapat mengoptimalkan hasil beajar siswa. 


\section{SIMPULAN DAN SARAN}

\section{Simpulan}

Berdasarkan hasil penelitian dapat disimpulkan bahwa penerapan model pembelajaran kooperatif tipe Talking Chips berbantuan media audio visual pada materi tata nama senyawa kelas X TSM 2 di SMK Negeri 1 Teluk Kuantan dapat meningkatkan hasil belajar siswa. Hal ini dapat dilihat dari hasil tes yang dilakukan pada setiap siklusnya dimana pada siklus I hasil belajar siswa memperoleh nilai rata___ rata 70, ketuntasan klasikal 60\%. Sedangkan pada siklus II hasil belajar siswa memperoleh nilai rata__rata 72,8, ketuntasan klasikal $85 \%$. Hal ini berarti bahwa hasil belajar siswa dari siklus I ke siklus II dinyatakan meningkat, yakni sebesar $25 \%$.

\section{Saran}

Pada penelitian ini penerapan model pembelajaran kooperatif tipe Talking Chips berbantuan video pembelajaran hanya dilakukan pada materi tata nama senyawa. Oleh karena itu, diharapkan pada penelitian serupa untuk menggunakan materi lain untuk melihat bagaimana keefektifan dari penerapan model pembelajaran kooperatif tipe Talking Chips berbantuan video pembelajaran.

\section{DAFTAR PUSTAKA}

Alimah, S. (2012). Pengembangan multimedia pembelajaran embriogenesis untuk mengoptimalkan pemahaman kognitif mahasiswa. Jurnal Pendidikan IPA Indonesia, 1(2), 131-140. https://doi.org/10.15294/jpii.v1i2.2130

Andriani, Y. (2017). Pengembangan model pembelajaran nobibasisku pada mata pelajaran biologi di SMA Negeri 6 OKU (modifikasi model pembelajaran kooperatif berbasis inkuiri). Didaktika Biologi, 1(1), 11-18. https://doi.org/10.32502/dikbio.v1i1.958

Asmarnis, Yuhelman, N., \& Murwindra, R. (2016). Media dan efektivitas belajar siswa untuk mewujudkan pendidikan yang berdaya saing tinggi. Jurnal Zarah, 4(1), 34-46. https://doi.org/10.31629/zarah.v4i1.171

Bayharti, Bahrizal, \& Fitriani, R. (2017). Penggunaan teknik talking chips pada model kooperatif hasil belajar dalam pembelajaran tata nama senyawa dan persamaan reaksi kimia di SMAN 2 Pariaman. Jurnal Entropi, 12(1), 7-14. https://doi.org/10.34312\%2Fjjec.v12i1.2203

Busyaeri, A., Udin, T., \& Zaenudin, A. (2016). Pengaruh penggunaan video pembelajaran terhadap peningkatan hasil belajar mapel IPA di MIN Kroya Cirebon. Al Ibtida: Jurnal Pendidikan Guru MI, 3(1), 116-137. https://doi.org/10.24235/al.ibtida.snj.v3i1.584

Dewi, M. A. C., Sugiarta, I. ., \& Suarsana, I. . (2015). Penerapan pembelajaran kooperatif teknik kancing gemerincing untuk meningkatkan keaktifan dan prestasi belajar matematika siswa SD. Jurnal Pendidikan Matematika Undiksha, 3(1), 1-10. Retrieved from https://ejournal.undiksha.ac.id/index.php/JJPM/article/view/5051/3814

Firdaus, M., \& Wilujeng, I. (2018). Pengembangan LKPD inkuiri terbimbing untuk meningkatkan keterampilan berpikir kritis dan hasil belajar peserta didik. Jurnal Inovasi 
Pendidikan IPA, 4(1), 26-40. https://doi.org/10.21831/jipi.v4i1.5574

Gutmann, J., Kühbeck, F., Berberat, P. O., \& Fischer, M. R. (2015). Use of learning media by undergraduate medical students in pharmacology: a prospective cohort study. PLOS ONE, 10(4), 1-11. https://doi.org/10.1371/journal.pone.0122624

Hamdu, G., \& Agustina, L. (2011). Pengaruh motivasi belajar siswa terhadap pestasi belajar IPA di sekolah dasar. Jurnal Penelitian Pendidikan, 12(1), 81-86. Retrieved from https://s3.amazonaws.com/academia.edu.documents/35968572/8-

Ghullam_Hamdu1.pdf?AWSAccessKeyId=AKIAIWOWYYGZ2Y53UL3A\&Expires=1 557969754\&Signature $=$ RxjYzdOOWnXBAzDUs7fVEWUOzVg\%3D\&responsecontent-disposition=inline\%3B filename\%3DPENGARUH_MOTIVASI_BELAJAR_SISWA_TERHADAP.pdf\%0D

Handayani, E. M. T., Prihatin, J., \& Fikri, K. (2018). The development of collaborative learning talking chips based on brain-based learning (BBL) for the junior high school science in the agroecosystem area. Pancaran Pendidikan, 7(4), 73-86. https://doi.org/10.25037/pancaran.v7i4.210

Hariyanto, Y., \& Asto, I. G. P. (2015). Pengaruh metode pembelajaran tipe talking chips terhadap hasil belajar siswa pada kompetensi dasar memahami model atom bahan semi konduktor di SMK Negeri 1 Jetis Mojokerto. Jurnal Pendidikan Teknik Elektro, 4(3), 999-1005. Retrieved from https://jurnalmahasiswa.unesa.ac.id/index.php/jurnalpendidikan-teknik-elektro/article/view/13004/4744

Hasairin, A., \& Apriyanti, D. (2018). Penerapan model pembelajaran kooperatif tipe talking chips pada materi keanekaragaman hayati di MAN 1 Medan. Jurnal Pelita Pendidikan, 6(4), 253-264. https://doi.org/10.24114/jpp.v6i4.11719

Insyasiska, D., Zubaidah, S., \& Susilo, H. (2015). Pengaruh project based learning terhadap motivasi belajar, kreativitas, kemampuan berpikir kritis, dan kemampuan kognitif siswa pada pembelajaran biologi. Jurnal Pendidikan Biologi, 7(1), 9-21. https://doi.org/10.17977/jpb.v7i1.713

Kurniawan, M. R. (2014). Penerapan media audio visual terhadap hasil belajar lompat jauh gaya jongkok siswa kelas IV SDN Bibis 113 Surabaya tahun ajaran 2013-2014. Jurnal Pendidikan Olahraga Dan Kesehatan, II(3), 559-563. Retrieved from https://jurnalmahasiswa.unesa.ac.id/index.php/jurnal-pendidikanjasmani/article/view/9983/9777

Kusmana, A. (2011). E-learning dalam pembelajaran. Lentera Pendidikan, 14(1), 35-51. https://doi.org/0.24252/lp.2011v14n1a3

Kusumaningrum, S., \& Djukri, D. (2016). Pengembangan Perangkat Pembelajaran Model Project Based Learning ( PjBL ) untuk Meningkatkan Keterampilan Proses Sains dan Kreativitas Developing a Learning Kit with Project Based Learning Model ( PjBL ) to Improve Scientific Process Skills and Creativity. Jurnal Inovasi Pendidikan IPA, 2(2), 241-251. Retrieved from http://journal.uny.ac.id/index.php/jipi Jurnal

Lestari, A. W. (2012). Pengembangan perangkat pembelajaran IPA SMP berbasis kooperatif tipe STAD pada tema fotosintesis di SMP GIKI-3 Surabaya. PENSA E-Jurnal, 1(1), 1-8. Retrieved from https://jurnalmahasiswa.unesa.ac.id/index.php/pensa/article/view/222/158

Nugroho, A. (2010). Rekayasa perangkat lunak berorientasi objek dengan metode USDP (unifeld software development process). Yogyakarta: Penerbit Andi. 
Putrayasa, I. M., Syahruddin, H., \& Margunayasa, I. G. (2014). Pengaruh model pembelajaran discovery learning dan minat belajar terhadap hasil belajar IPA siswa. Jurnal Mimbar PGSD Universitas Pendidikan Ganesha, 2(1). Retrieved from https://ejournal.undiksha.ac.id/index.php/JJPGSD/article/view/3087/2561

Sari, D. S., \& Sugiyarto, K. H. (2015). Pengembangan multimedia berbasis masalah untuk meningkatkan motivasi belajar dan kemampuan berpikir kritis siswa. Jurnal Inovasi Pendidikan IPA, 1(2), 153-166. https://doi.org/10.21831/jipi.v1i2.7501

Satriani, N. N., Manuaba, I. B. ., \& Negara, I. G. A. . (2018). Pengaruh model pembelajaran talking chips berbasis lesson study terhadap hasil belajar ipa siswa kelas IV SD. Journal for Lesson and Learning Studies, 1(1), 1-10. Retrieved from https://ejournal.undiksha.ac.id/index.php/JLLS/article/view/14617/8934

Sukardi, S. (2012). Strategi pembelajaran berorientasi standar proses pendidikan. Jakarta: Kencana Prenada Media Group.

Suryosubroto. (2009). Proses belajar mengajar di sekolah. Jakarta: Rineka Cipta.

Susilowati, I., Iswari, R. S., \& Sukaesih, S. (2013). Pengaruh pembelajaran berbasis proyek terhadap hasil belajar siswa materi sistem pencernaan manusia. Unnes.J.Biol.Educ., 2(1), 82-90.

Retrieved

from https://journal.unnes.ac.id/sju/index.php/ujbe/article/view/2618/2408

Taufiq, M., Dewi, N. R., \& Widiyatmoko, A. (2014). Pengembangan media pembelajaran IPA terpadu berkarakter peduli lingkungan tema "konservasi" berpendekatan scienceedutainment. Jurnal Pendidikan IPA Indonesia, 3(2), 140-145. Retrieved from https://journal.unnes.ac.id/nju/index.php/jpii/article/viewFile/3113/3130

Tivani, I., \& Paidi. (2016). Pengembangan LKS biologi berbasis masalah untuk meningkatkan kemampuan pemecahan masalah dan karakter peduli lingkungan. Jurnal Inovasi Pendidikan IPA, 2(1), 35-45. https://doi.org/10.21831/jipi.v2i1.8804

Wibawa, L. P. A. N. P., Wirya, I. N., \& Tegeh, I. M. (2016). Pengaruh model pembelajaran talking chips terhadap hasil belajar IPA siswa kelas V. E-Journal PGSD Universitas Pendidikan Ganesha, 4(1), 1-11. Retrieved from https://ejournal.undiksha.ac.id/index.php/JJPGSD/article/view/7429/5072

Widiyawati, Y., \& Nurwahidah, I. (2018). Elclivs berbasis inquiry untuk meningkatkan penguasaan konsep siswa tuna netra pada materi rangkaian listrik. Jurnal Inovasi Pendidikan IPA, 4(2), 212-223. https://doi.org/10.21831/jipi.v4i2.21527

Yanda, A. B., Asrul, \& Yusnetti. (2013). Pengaruh peggunaan teknik talking chips terhadap hasil belajar IPA fisika siswa kelas VII SMPN 1 IV Jurai Kabupaten Pesisir Selatan. Pillar Of Physics Education, IV, 97-103. https://doi.org/10.24036/497171074

Yusuf, M. M., Amin, M., \& Nugrahaningsih. (2017). Developing of instructional media-based animation video on enzyme and metabolism material. Jurnal Pendidikan Biologi Indonesia, 3(3), 254-257. https://doi.org/10.22219/jpbi.v3i3.4744

\section{PROFIL SINGKAT}

Qurratun Khairina, S.Pd menempuh pendidikan strata satu pada Program Studi Pendidikan Kimia Universitas Islam Kuantan Singingi 
Nofri Yuhelman, S.Pd., M.Pd. merupakan pengajar di Program Studi Pendidikan Kimia Universitas Islam Kuantan Singingi. Pendidikan strata satu ditempuh di Program Studi Pendidikan Kimia Universitas Negeri Padang, dan magister di Pendidikan Kimia Universitas Pendidikan Indonesia.

Jumriana Rahayuningsih, S.Pd., M.Si., merupakan pengajar di Program Studi Pendidikan Kimia Universitas Islam Kuantan Singingi. Pendidikan strata satu ditempuh di Program Studi Pendidikan Kimia Universitas Negeri Padang, dan magister di Prrogram Studi Kimia Material Universitas Andalas. 